\title{
Integrasi Perilaku Sosial Dalam Pembelajaran Pendidikan Jasmani
}

\section{Integration of Social Behavior in Physical Education Learning}

\author{
Anna Mariam Sofiarini*, Nurlan Kusmaedi, dan Amung Ma'mun \\ Universitas Pendidikan Indonesia, Bandung, Jawa Barat, Indonesia \\ annamsofiarini11@upi.edu*,nurlankusmaedi@upi.edu,amung@upi.edu
}

Naskah diterima tanggal 20/07/2019, direvisi akhir tanggal 11/03/2020, disetujui tanggal 28/04/2020

\begin{abstract}
Abstrak
Penelitian ini bertujuan untuk mengetahui perbedaan dari hasil pretest dan posttest pada kelompok eksperimen dan kelompok kontrol, serta untuk mengetahui perbedaan yang signifikan antara kelompok eksperimen dan kelompok kontrol. Metode penelitian eksperimen dengan desain penelitian pretest-posttest control group design pada siswa di SMA Istiqamah Bandung kelas $\mathrm{X}$ yakni yang jumlahnya sebanyak 120 orang, dan untuk yaitu 60 siswa yang dibagi menjadi 2 kelompok setelah dilakukan pretest. Instrumen adalah angket atau kuisioner. Sebelumnya diuji angket terlebih dahulu dari 50 pernyataan menjadi 42 butir pernyataan. Hasil dari penelitian ini ialah hipotesis 1 bahwa kelompok eksperimen siswa didapatkan hasil 5000 pada pretest, sedangkan didapatkan hasil 5232 pada posttest. Dari hasil kedua test tersebut didapat hasil perbedaannya sebanyak 232. Uraian deskripsi di atas menunjukan bahwa terdapat perbedaan dari hasil pretest dan positest kelompok eksperimen. Uji hipotesis 2 bahwa kelompok kontrol siswa didapatkan hasil 5000 pada pretest, sedangkan didapatkan hasil 5026 pada posttest. Dari hasil kedua test tersebut didapat hasil perbedaannya sebanyak 26. Uraian deskripsi di atas menunjukan bahwa terdapat perbedaan dari hasil pretest $\mathrm{d}$ an posttest kel ompok kon trol. Uji hip otesis $3 \mathrm{~b}$ ah wa ter dapat per bedaan yan $\mathrm{g}$ signifikan antara kelompok eksperimen dan kelompok kontrol pada penelitian ini karena t hitung $>$ dari t tabel yaitu 1,81 $>1,70$ diperkuat dengan hasil $\mathrm{P}$-value $<0,05$ yaitu $0,04<0,05$. Maka keterangan dari hasil penelitian ini menunjukkan terdapat perbedaan dari hasil pretest dan posttest kelompok eksperimen dan kelompok kontrol, serta terdapat perbedaan yang signifikan antara kelompok eksperimen dan kelompok kontrol.
\end{abstract}

Kata Kunci: Pembelajaran Pendidikan Jasmani, Perilaku Sosial.

\begin{abstract}
The study aims to determine the differences from the results of the pretest and positest in the experimental group and the control group, as well as to find out the significant differences between the experimental group and the control group. The experimental research method with the design of the pretest-positest control group design study in students in Bandung's Istiqamah High School class X was 120 people. For that, 60 students were divided into two groups after the pretest. Instruments are questionnaires or questionnaires. Previously the questionnaire was tested from 50 statements to 42 items. The results of this study are hypothesis 1 that the experimental group of students obtained 5000 results at the pretest, while the results obtained 5232 at the positest. From the results of the two tests, the results of the differences were 232. The description of the description above shows that there are differences from the results of the experimental group's pretest and positest. Test the hypothesis 2 that the student control group obtained 5000 results at the pretest, while the results obtained 5026 at the positest. From the results of the two tests, the results of the differences were 26. The description of the description above shows that there are differences from the results of the control group's pretest and positest. Hypothesis 3 tests that there are significant differences between the experimental group and the control group in this study because tcount $>$ from t table is $1.81>1.70$ strengthened by the P-value $<0.05$, which is
\end{abstract}


$0.04<0.05$. Then the information from the results of this study shows there are differences from the results of the experimental group pretest and posttest and the control group, and there are significant differences between the experimental group and the control group.

Keywords: Physical Education Learning, Social Behavior.

\section{PENDAHULUAN}

Aktivitas pendidikan jasmani (penjas) secara langsung dapat mempengaruhi perkembangan sosial, namun perilaku sosial dianggap menjadi salah satu masalah utama untuk aktivitas penjas di antara anak remaja (Dos Santos et al., 2015). Sekolah adalah lingkungan di mana siswa belajar dan pada saat yang sama, dapat mencoba berbagai perilaku sosial yang terkait dengan keseimbangan kekuasaan, peran, tekanan teman sebaya, aturan-aturan sosial, kerjasama, persaingan, resolusi konflik, pengambilan keputusan, kepemimpinan, tanggung jawab, dan sebagainya dalam konteks ini, penjas merupakan salah satu mata pelajaran sekolah yang dapat memberikan kontribusi signifikan terhadap siswa pribadi dan pembangunan sosial (Iyer et al., 2010; Feşteu., 1998).

Untuk mencapai pembangunan sosial di tingkat kepribadian individu, dalam hal hubungan interpersonal dan perilaku kelompok, dipandang sebagai perkembangan sosial manusia, sadar dan bawah sadar, kognitif, emosional, sikap, kehendak dan kreatif, yang terjadi sebagai hasil belajar kelembagaan dan ekstrakurikuler pada pembelajaran sosial dan pendidikan (Raluca., 2015), selain itu konteks sosial yang melibatkan faktor-faktor lingkungan terutama umumnya dimanipulasi oleh guru dalam pengaturan pendidikan, yang mempengaruhi keinginan (minat) atau motivasi siswa (Deci \& Ryan., 1985; Vallerand \& Losier., 1999).

Pendidikan dilihat dari sudut pandang tertentu akan berbeda pengertiannya akan tetapi maksud yang tertuju pada peningkatan kualitas sumber daya manusia. Dalam Undang-Undang Sistem Pendidikan Nasional nomor 20 tahun 2003 disebutkan bahwa pendidikan adalah usaha sadar dan berencana untuk mewujudkan suasana belajar dan proses pembelajaran agar peserta didik aktif menggembangkan potensi dirinya untuk memiliki kekuatan spritual keagamaan, pengendalian diri, kepribadian, kecerdasan, akhlak mulia, serta keterampilan yang diperlukan dirinya, masyarakat, bangsa dan negara (Undang-Undang Sistem Pendidikan Nasional., 2003).

Pendidikan jasmani dilaksanakan melalui aktivitas fisik yang bertujuan mendidik siswa secara jasmani dengan materi pembelajaran aktivitas jasmani yang dilakukan dengan permainan menyerupai olahraga. Dengan permainan tersebut dapat mewujudkan tujuan dari pendidikan melalui pembelajaran pendidikan jasmani yang muara akhir dari pembelajaran tersebut ialah siswa yang terdidik secara utuh (fisikal, mental, sosial, emosional).

Pendidikan jasmani mempunyai banyak ciri unik yang dapat dilihatnya selain dari proses pembelajaran, proses pengajaran, sarana dan prasana serta alat atau media yang digunakannya. Pendidikan jasmani dituntut untuk memberikan pembelajaran sesuai dengan yang ada dalam kurikulum juga aturan yang sudah baku serta panduan atau petunjuk yang telah dirancang sebelumnya oleh pengajar tersebut namun didalam proses belajar mengajarnya dibuat sedemikian rupa untuk menimbulkan susasana yang selalu menggembirakan, menyenangkan, tidak membosankan, dan menarik. Sehingga setiap siswa yang mengikutinya secara tidak langsung dan tidak sadar akan apa yang telah dipelajarinya mempunyai banyak manfaat bagi peserta didiknya.

Dengan demikian pendidikan jasmani dalam pembelajarannya memiliki beberapa aspek penting yang secara tidak langsung berjalan bersamaan dalam proses pembelajaran dapat dimiliki setiap peserta didik. Aspek tersebut diantaranya yaitu, pertama adalah aspek psikomotor atau yang 
sering dikenal dengan aspek keterampilan yang biasanya bertumpu pada perkembangan kemampuan biologis organ tubuh/fisik yang dapat dilihat secara langsung dari teknik atau penguasaan gerak siswa tersebut dalam mempelajari penjas. Kemudian aspek kognitif atau aspek pengetahuan yang mencakup fakta-fakta, konsep, penalaran, pemahaman, hafalan dan kemampuan memecahkan masalah yang dapat siswa terapkan atau ketahui mengenai sejarah, tata cara, teori, atau apapun yang berhubungan dengan penjas. Dan aspek afektif atau aspek sikap yang mencakup sifat-sifat psikologi yang menjadi unsur kepribadian yang kokoh, yang dapat mencerminkan sikap seorang siswa didalam suatu kegiatan pembelajaran penjas. Tidak hanya tentang sikap sebagai kesiapan berbuat yang perlu dikembangkan, tetapi yang lebih penting adalah konsep diri dalam komponen kepribadian lainnya.

Namun terkadang timbul permasalahan dalam pembelajaran pendidikan jasmani menyangkut dalam aspek afektif yaitu mengenai perilaku sosial siswa. Masalah perilaku sosial siswa yang timbul pada anak sekolah menengah atas dapat mempengaruhi kepribadian setiap individunya, seperti tujuan dari proses penjas tidak hanya pada aspek psikomotor saja, tetapi mencakup aspek kognitif dan afektif. Disamping aspek kognitif dan psikomotor, aspek afektif juga harus dimiliki siswa karena sangat erat hubungannya dengan perilaku siswa. Perilaku siswa saat ini baik individu maupun beregu masih ada yang belum dapat menyesuaikan diri dengan lingkungannya, memilihmilih teman dan kurangnya bersosialisasi dengan teman lainnya disekolah. Perilaku sosial siswa sangat penting adanya pada setiap siswa terutama pada siswa sekolah menengah atas dikarenakan siswa memasuki fase remaja (15-18 tahun) dimana pada fase ini identik dengan pencarian jati diri dan timbul dorongan untuk mencari sesuatu yang dipandang bernilai dan pantas dijunjung tinggi. Pada fase remaja inilah masih banyak siswa yang dapat terpengaruhi oleh lingkungan yang terutama oleh teman sebayanya sehingga perilaku sosial siswa sangat erat kaitannya dengan pembelajaran penjas. Karena dalam pembelajaran penjas dapat dilihat seberapa besar perilaku sosial berperan penting bagi siswa. Seperti pada saat pembelajaran penjas berlangsung siswa dibutuhkan kerjasama untuk melakukan suatu kegiatan yang dilakukan secara berkelompok, dengan demikian siswa secara tidak langsung harus ketergantungan dengan kelompoknya agar mendapatkan hasil yang maksimal. Dari kerjasama tersebut dapat dilihat perilaku sosial yang ada di setiap individunya

Kegiatan belajar mengajar memiliki fungsi pokok dan usaha yang paling strategis guna mewujudkan tujuan institusional yang digunakan oleh lembaga sekolah. Di tangan para gurulah tersimpan kemungkinan berhasil atau tidaknya pencapaian yang ada di sekolah dari tujuan pendidikan. Dengan kata lain agar guru mampu menunaikan tugasnya dengan baik maka terlebih dahulu harus memahami dengan baik halhal yang bertalian dengan proses belajar mengajar. Siswa, yang harus terus berusaha menggembangkan dirinya secara optimal melalui berbagai kegiatan (belajar) guna mncapai tujuaannya sesuai dengan tahapan perkembangan yang dijalaninya. Dengan tujuan yang merupakan seperangkat tugas atau tuntutan atau kebutuhan yang harus dipenuhi atau sistem nilai yang harus tampak dalam perilaku dan merupakan karakteristik kepribadian siswa yang sepenuhnya diterjemahkan dalam berbagai bentuk kegiatan yang berencana dan dapat dievaluasi (terukur). Selain itu guru harus selalu mengusahakan terciptanya situasi yang tepat (mengajar) sehingga memungkinkan terjadinya proses pengalaman belajar pada diri siswa, dengan menggerahkan seluruh sumber dan menggunakan strategi belajar mengajar yang tepat (Makmun., 2007).

$$
\text { Memperhatikan penjelasan di }
$$

atas bahwa dalam konteks Proses Belajar Mengajar (PBM) terutama dalam kaitannya dengan tiga komponen yang utama, ada tiga yang harus dipahami oleh guru, ialah hakikat atau konsep dasar serta terjadinya perilaku belajar pada diri siswa, kriteria dan cara merumuskan tujuan belajar mengajar 
dalam bentuk yang operasional yang dapat dipandang sebagai manifesta hasil perilaku belajar siswa yang secara langsung dapat diamati dan dapat dievaluasi, dan karakteristik utama, termasuk segi-segi kebaikan dan kelemahanya dari beberapa model strategi belajar mengajar yang umum, serta kriteria yang dapat digunakan untuk memilihnya bagi keperluan penggunaannya.

Sehubungan dengan itu keberadaan manusia sebagai mahkluk sosial yang mempunyai reaksi/respon dengan baik mengakibatkan suatu peristiwa saling mempengaruhi antara individu yang satu dengan yang lain, dari peristiwa tersebut menghasilkan interaksi-interaksi yang dinamakan perilaku sosial. Menurut Budiman. (2007) perilaku sosial adalah suasana saling ketergantungan yang meupakan keharusan untuk menjamin keberadaan manusia. Selanjutnya pendapat Krech et al., (1982) perilaku sosial seseorang itu tampak dalam pola respon antar orang perilaku itu dinyatakan dalam hubungan timbal balik antar pribadi. Sebagai mahkluk sosial, individu senantiasa mengadakan suatu hubungan dengan individu lainnya, dalam aktivitas-aktivitas yang menampilkan seorang individu dalam mewujudkan hubungan interaksi yang disebut dengan perilaku sosial. Perilaku sosial indentik dengan reaksi seseorang terhadap orang lain. Perilaku itu ditunjukkan dengan perasaan, tindakan, sikap, keyakinan, kenganan, atau rasa hormat terhadap orang lain (Baron \& Bryne., 1991). Mengenai perilaku sosial adalah aktivitas yang dilakukan oleh seseorang untuk berkomunikasi dengan lingkungannya (Mustika., 2013).

Berdasarkan pada pendapat para ahli tentang perilaku sosial penulis mengemukakan bahwa perilaku sosial merupakan aktivitas untuk mencapai tujuan yang diinginkan, untuk memperoleh tujuan tersebut dibutuhkan suatu kerja sama atau interaksi antar individu, sehingga timbul sebuah reaksi atau respon dari individu lain. Reaksi yang timbul menandakan individu tersebut memperhatikan orang yang memberi masukan. Dalam interksi tersebut terdapat proses saling merespon, saling menghargai, menghormati, mempengaruhi dan saling menyesuaikan diri dengan lingkungan sosialnya.

Perilaku seseorang tidak cukup hanya tertuju pada kepentingan diri pribadi. Ia harus mampu bekerja sama, toleransi, sabar, tidak menganggu kepentingan orang lain, murah hati dan diharapkan dapat menerima nilainilai atau aturan yang ada di masyarakat, sehingga dapat menjalankan tatanan hidup di masyarakat. Sebagai mahkluk sosial, seorang individual sejak lahir hingga sepanjang hayatnya senantiasa berhubungan dengan individu lainnya atau dengan berbagai aktivitas tertentu, baik aktivitas yang dihasilkan berdasarkan naluri semata atau justru melalui proses pembelajaran tertentu. Berbagai aktivitas individu dalam relasi interpersonal ini biasa disebut perilaku sosial. Perilaku sosial tersebut sesuai dengan tuntutan sosial atau masyarakat. Hal tersebut diperjelas Hurlock. (1997) yang mengemukakan bahwa perkembangan sosial berarti perolehan kemampuan berperilaku yang sesuai dengan tuntutan sosial, menjadi orang yang mampu bermasyarakat memerlukan tiga proses yang masing-masing berbeda satu sama lain tetapi saling berkaitan. Sehingga kegagalan dalam suatu poses akan menurunkan kadar sosial individu.

Social Cognitive Theory menurut Bandura. (1999) berfungsi sebagai kerangka kerja untuk memahami aktivitas fisik remaja selama pendidikan jasmani. Teori kognitif sosial menekankan bahwa tindakan dipengaruhi oleh faktor pribadi, lingkungan dan perilaku yang dinamis dan selalu berinteraksi (Bandura., 1999). Diterapkan pada pendidikan jasmani, teori kognitif sosial menunjukkan bahwa faktor lingkungan, seperti konteks kelas, isi pelajaran, dan perilaku guru, mempengaruhi perilaku murid secara langsung atau tidak langsung melalui perubahan yang menentukan dalam kepribadian seseorang (misalnya kesenangan, kemampuan seseorang). Berbagai intervensi pembelajaran keterampilan sosial sudah efektif dalam meningkatkan keterampilan sosial yang sesuai dalam lingkungan 
pendidikan. Pengajaran keterampilan sosial, berdasarkan teori belajar sosial menurut Bandura. (1977) lebih menekankan hal yang positif untuk dapat menggantikan perilaku negatif dengan hal yang lebih baik dilakukan siswa dan untuk mengajar siswa lebih membangun perilaku sosial yang bermanfaat untuk kedepannya (Cartledge et al., 2008; Chen., 2006). Instruksi ini biasanya melibatkan contoh perilaku sosial, umpan balik, praktik langsung, penguatan, mencoba berperilaku, dan perubahan perilaku (Moore et al., 1995). Berdasarkan teori belajar sosial, sebagian besar perilaku dipelajari dan dengan demikian instruksi langsung dapat digunakan untuk mengajarkan perilaku sosial yang sesuai (Ormrod., 1999).

Tujuan utama dalam mengembangkan orang yang berpendidikan fisik adalah untuk membantu siswa terlibat dalam perilaku sosial yang positif (NAPSE., 2004). Sebagai contoh, akan lebih menguntungkan bagi siswa untuk terlibat dalam perilaku prososial lebih sering. Statistik yang terakhir ini sejalan dengan statistik nasional bahwa sekitar $41 \%$ siswa diintimidasi setidaknya satu kali selama masa sekolah (Nansel et al., 2001). Oleh karena itu, beberapa tingkat perilaku intimidasi dan antisosial umum terjadi di antara siswa pendidikan jasmani sekolah menengah. Mengingat keinginan untuk memperkuat perilaku sosial yang positif dan mengurangi perilaku intimidasi dan dampak buruknya terhadap kesehatan mental (Kaltiala-Heino et al., 2000).

Perilaku pada seseorang dilakukan secara sosial seperti bekerja sama, toleransi, sabar, tidak menganggu kepentingan orang lain, murah hati dan diharapkan dapat menerima nilai-nilai atau aturan yang ada di masyarakat, sehingga dapat menjalankan tatanan hidup di masyarakat. Sebagai mahkluk sosial, seseorang individu sejak lahir hingga sepanjang hayatnya senantiasa berhubungan dengan individu lainnya atau dengan berbagai aktivitas tertentu, baik aktivitas yang dihasilkan berdasarkan naluri, semata atau justru melalui proses pembelajaran tertentu. Berbagai aktivitas individu dalam relasi interpersonal ini biasa disebut perilaku sosial. Perilaku sosial tersebut sesuai dengan tuntutan sosial atau masyarakat. Untuk meningkatkan perilaku sosial dapat melalui pendidikan jasmani (Dragnea et al., 2000; Iyer et al., 2010; Feşteu., 1998).

\section{METODE PENELITIAN}

Metode dalam penelitian ini menggunakan metode eksperimen dimana menurut Gratton. (2010) menjelaskan metode atau desain eksperimen digunakan secara umum untuk mengetahui sebuah pengaruh dari variabel bebas terhadap variabel terikat.

Salah satu metodologi penelitian yang memiliki beberapa karakteristik diantaranya, memanipulasi variabel bebas, melakukan pengacakan dalam menentukan sampel penelitian, dan membandingkan kelompok eksperimen dengan kelompok kontrol. Dalam penelitian ini ada suatu manipulasi atau perlakuan (treatment) pada salah satu kelompok, yaitu menyatukan pendekatan permainan dalam setiap materi pembelajaran pada kelompok eksperimen. Kemudian menerapkan pembelajaran pendidikan jasmani dan olahraga dengan menggunakan materi pembelajaran biasa pada kelompok kontrol. Perlakuan (treatment) diberikan selama beberapa pertemuan terhadap kedua kelompok, hingga terjadi perubahan dan dirasa cukup oleh peneliti.

Desain penelitian yang digunakan adalah pretest-postest control group design. Penelitian ini melibatkan siswa sekolah menengah atas kelas $\mathrm{X}$ sebagai partisipan. Tempat pelaksanaan penelitian adalah Sekolah Menengah Atas Swasta Istiqamah. Program pada penelitian ini akan dilaksanakan 3 kali pertemuan dalam seminggu, sebagai percobaan untuk mendapatkan hasil yang baik dan biasanya dilaksanakan dalam frekuensi 3 hari/minggu, sedangkan lamanya latihan/pembelajaran paling sedikit 4-6 minggu (Juliantine., 2007).

Populasi adalah sekumpulan objek, orang atau keadaan yang menjadi perhatian peneliti dan akan digunakan oleh peneliti untuk menggeneralisasikan hasil penelitiannya (Fraenkel et al., 2013). Dapat disimpulkan bahwa populasi dalam penelitian 
ini adalah seluruh siswa di SMA Istiqamah kelas $\mathrm{X}$ yakni yang jumlahnya sebanyak 120 orang. Teknik pengambilan sampel atau teknik sampling adalah suatu cara mengambil sampel yang representatif dari populasi (Fraenkel et al., 2013). Sampel adalah sebagian dari populasi yang diteliti. Dengan kata lain, sampel merupakan sebagian atau bertindak sebagai perwakilan dari populasi sehingga hasil penelitian yang berhasil diperoleh dari sampel dapat digeneralisasikan pada populasi (6 n.d.). Teknik sampling yang digunakan adalah simple random sampling dari populasi yang ada ialah 120 orang kemudian peneliti mengambil 50\%, jadi sampel yang di dapat ialah 60 orang yang kemudian dibagi menjadi 2 kelompok dan terdiri dari 30 orang kelompok eksperimen dan 30 orang kelompok kontrol.

Instrumen penelitian menggunakan obeservasi dan angket yang merupakan cara yang paling efektif (Arikunto., 2006) dalam penelitian ini. Angket yang dibuat ialah mengikuti dari komponen dan sub komponen serta indikator yang sesuai dari teori perilaku social. Menurut Krech et al., (1982) perilaku berperan (pemberani, berkuasa, inisiatif, mandiri), kemudian perilaku dalam hubungan sosial (dapat menerima atau ditolak oleh seseorang, suka bergaul atau tidak bergaul, sifat ramah dan tidak ramah, simpatik atau tidak simpatik), dan perilaku ekspresif (sifat suka bersaing / tidak kooperatif) dan suka kerjasama (sifat agresif dan tidak agresif, sifat kalem atau sifat tenang secara sosial, sifat suka pamer) yang digabungkan dengan teori proses pembelajaran menurut Makmun. (2007) ialah siswa (bakat, motivasi, minat, sikap) kemudian sarana (metode / model, guru, materi, alat) selain itu ialah

lingkungan (kebudayaan, sosial, fisik) dan yang terakhir ialah hasil belajar (kognitif, afektif, psikomotor). Untuk mengenai alternatif jawaban dalam lembar angket, penulis menggunakan skala sikap yang sering digunakan dalam sebuah penelitian yaitu skala likert (Sugiyono., 2013) dengan skor alternatif jawaban ada yang positif dan negatif. Untuk alternatif jawaban sangat setuju skor positif ialah 5 sedangkan, negatif ialah 1, untuk alternatif jawaban setuju skor positif ialah 4 sedangkan negatif ialah 2, untuk alternatif jawaban tidak setuju skor positif ialah 2 sedangkan negatif ialah 4, untuk alternatif jawaban sangat tidak setuju skor positif ialah 1 sedangkan negatif ialah 5, untuk alternatif jawaban ragu-ragu peneliti tidak menggunakannya karena tidak akurat jika sample menjawab pernyataan dengan ragu-ragu.

Penelitian ini dilaksanakan 3 kali seminggu selama 14 kali pertemuan (Juliantine., 2007), jadi penelitian ini dilakukan kurang lebih selama 4 minggu. Sebelum dilanjutkan ke langkah penelitian, peneliti melakukan uji angket terlebih dahulu kemudian dilanjutkan dengan langkahlangkah yang dilakukan dalam penelitian yang diintegrasikan perilaku sosial dan yang tanpa integrasi perilaku sosial dalam pembelajaran penjas.

Analisis data yang digunakan ialah dengan mencari rata-rata, simpangan baku dan standar deviasi terlebeih dahulu yang kemudian dilakukan uji normalitas dan uji homogenitas dan uji hipotesis (One Way ANOVA). Peneliti mengerjakan dengan menggunakan Microsoft excel.

\section{HASIL DAN PEMBAHASAN \\ 3.1. Hasil}

Tabel 1. Kelompok Esperimen (integrasi perilaku sosial)

\begin{tabular}{lclc}
\hline \multicolumn{4}{c}{ Kelompok Eksperimen } \\
\hline \multicolumn{3}{c}{ Pretest } \\
\hline Mean & 166,7 & Mean & 174,4 \\
\hline Standard Error & 1,2 & Standard Error & 1,0 \\
\hline Standard Deviation & 6,7 & Standard Deviation & 5,7 \\
\hline Sum & 5000 & Sum & 5232 \\
\hline Count & 30 & Count & 30 \\
\hline Confidence Level $(95,0 \%)$ & 2,5 & Confidence Level $(95,0 \%)$ & 2,1 \\
\hline
\end{tabular}


Berdasarkan tabel 1 kelompok eksperimen (integrasi perilaku sosial) diperoleh jumlah skor 5000 untuk pretest sedangkan jumlah skor 5232 untuk positest dan rata-rata sebesar 166,7 untuk pretest sedangkan rata-rata sebesar 174,4 untuk positest dengan simpangan baku yang diperoleh sebesar 6,7 untuk pretest dan 5,7 untuk positest.

Tabel 2. Kelompok Kontrol (tanpa integrasi perilaku sosial)

\begin{tabular}{lclc}
\hline \multicolumn{4}{c}{ Kelompok Kontrol } \\
\hline Pretest & \multicolumn{2}{c}{ Posttest } \\
\hline Mean & 166,7 & Mean & 167,5 \\
\hline Standard Error & 1,3 & Standard Error & 1,3 \\
\hline Standard Deviation & 7,0 & Standard Deviation & 6,9 \\
\hline Sum & 5000 & Sum & 5026 \\
\hline Count & 30 & Count & 30 \\
\hline Confidence Level (95,0\%) & 2,6 & Confidence Level $(95,0 \%)$ & 2,6 \\
\hline
\end{tabular}

Berdasarkan tabel 2 kelompok kontrol (tanpa integrasi perilaku sosial) diperoleh jumlah skor 5000 untuk pretest sedangkan jumlah skor 5026 untuk posttest dan ratarata sebesar 166,7 untuk pretest sedangkan rata-rata sebesar 167,5 untuk positest dengan simpangan baku yang diperoleh sebesar 7,0 untuk pretest dan 6,9 untuk positest.

Uji normalitas yang dilakukan pada pretest di atas untuk kelompok eksperimen dan kelompok kontrol dengan taraf signifikansi 0,05 dari 30 sampel ialah 0,161. Maka hasil pada kelompok eksperimen ialah $0,11<0,161$ maka data tersebut dinyatakan normal, sedangkan hasil pada kelompok kontrol ialah 0,10<0,161 maka data tersebut dinyatakan normal. Sedangkan uji normalitas pada posttest di atas untuk kelompok eksperimen dan kelompok kontrol dengan taraf signifikansi 0,05 dari 30 sampel ialah 0,161. Maka hasil pada kelompok eksperimen ialah $0,14<0,161$ maka data tersebut dinyatakan normal, sedangkan hasil pada kelompok kontrol ialah 0,10 $<0,161$ maka data tersebut dinyatakan normal. Dengan demikian dapat disimpulkan bahwa variable penelitian keempat data dari kelompok eksperimen (pretest dan positest) dan kelompok kontrol (pretest dan posttest) tersebut berdistribusi normal.

Uji homogenitas yang dilaukan untuk kelompok eksperimen didapatkan hasil $1,39<1,86$ maka data tersebut dinyatakan homogen. Sedangkan uji homogenitas untuk kelompok kontrol didapatkan hasil 1,05 < 1,86 maka data tersebut dinyatakan homogen.

Untuk hasil dari uji hipotesis, di dapat bahwa pada uji hipotesis pertama yang berbunyi bahwa: Terdapat perbedaan dari hasil pretest dan posttest kelompok eksperimen.

\section{Kelompok Eksperimen}

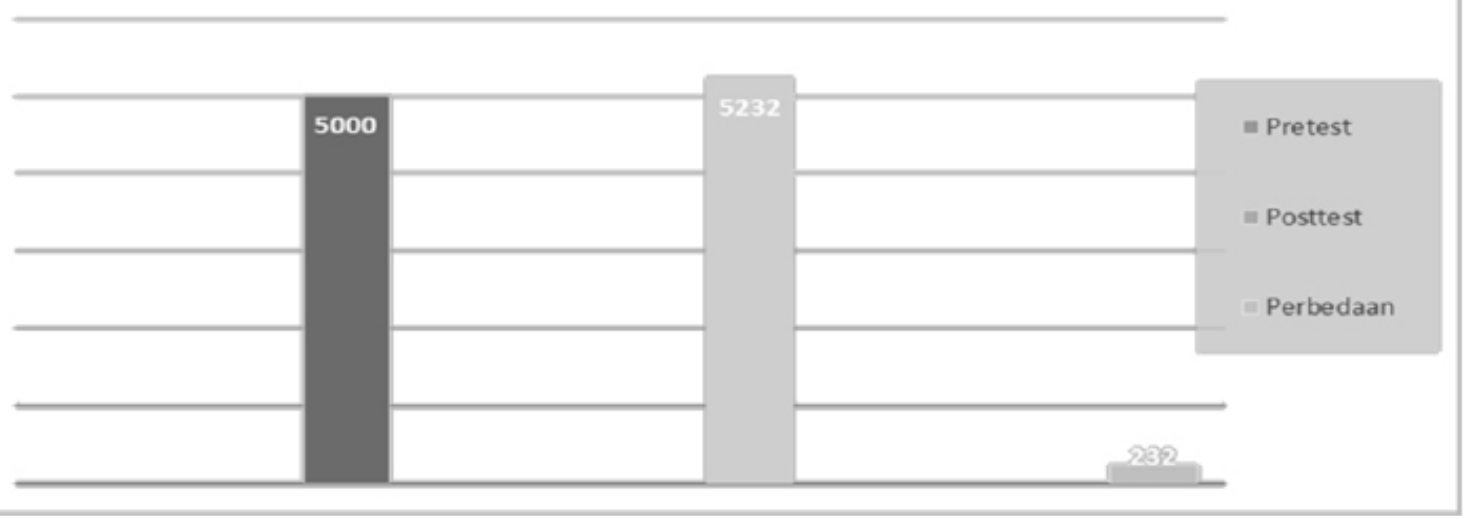

Grafik 1. Kelompok Eksperimen 
Berdasarkan grafik 1 pada hasil penelitian Kelompok Eksperimen siswa didapatkan yaitu hasil 5000 pada pretest, sedangkan didapatkan hasil 5232 pada posttest. Dari hasil kedua test tersebut didapat hasil perbedaannya sebanyak 232. Sedangkan pada uji hipotesis kedua yang berbunyi bahwa terdapat perbedaan dari hasil pretest dan posttest kelompok kontrol.

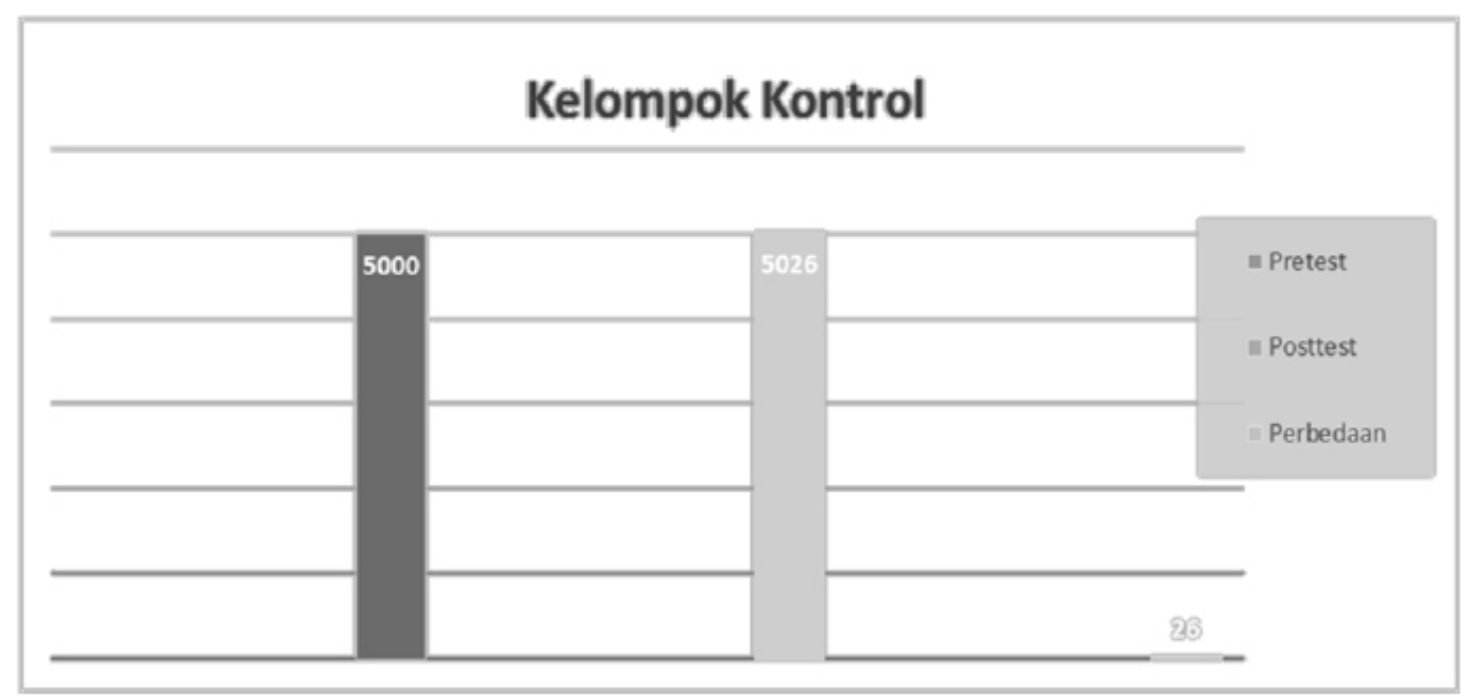

Grafik 2. Kelompok Kontrol

Berdasarkan grafik 2 pada hasil hasil perbedaannya sebanyak 26. Dan pada penelitian Kelompok Kontrol siswa didapatkan hasil 5000 pada pretest, sedangkan didapatkan hasil 5026 pada posttest. Dari hasil kedua test tersebut didapat uji hipotesis ketiga yang berbunyi bahwa terdapat perbedaan yang signifikan antara kelompok eksperimen dan kelompok kontrol.

Tabel 3. t-Test: Two-Sample Assuming Unequal Variances

\begin{tabular}{lrr}
\hline \multicolumn{1}{c}{ Hasil Selisih } & Eksperimen & Kontrol \\
\hline Mean & 15,27 & 1,60 \\
\hline Variance & 1679,72 & 21,63 \\
\hline Observations & 30 & 30 \\
\hline Hypothesized Mean Difference & 0 & \\
\hline$d f$ & 30 & \\
\hline$t$ Stat & 1,81 & \\
\hline$P(T<=t)$ one-tail & 0,04 & \\
\hline$t$ Critical one-tail & 1,70 & \\
\hline
\end{tabular}

Berdasarkan tabel 3 pada $t$-Test: TwoSample Assuming Unequal Variances hasil penelitian yang telah dilakukan dilihat dari selisih yang didapat dari setiap kelompoknya, maka didapatkan hasil $t_{\text {hitung }}$ sebesar 1,81 sedangkan $t_{\text {tabel }} 1,70$ dan P-value 0,04 . Uraian deskripsi di atas menunjukan bahwa terdapat perbedaan yang signifikan antara kelompok eksperimen dan kelompok kontrol pada penelitian ini karena $\mathrm{t}_{\text {hitung }}>$ dari $\mathrm{t}_{\text {tabel }}$ yaitu $1,81>1,70$ diperkuat dengan hasil $\mathrm{P}$-value $<$
0,05 yaitu $0,04<0,05$.

\subsection{Pembahasan}

Berdasarkan temuan penelitian yang telah dipaparkan di atas, bahwa terdapat perbedaan dari hasil pretest dan posttest pada kelompok eksperimen dengan hasil perbedaannya sebesar 232. Sedangkan dari hasil pretest dan posttest pada kelompok kontrol didapat perbedaannya hanya sebesar 26. Sesuai dengan yang ada dari penelitian terdahulu bahwa untuk meningkatkan 
perilaku sosial dapat melalui pendidikan jasmani (Dragnea et al., 2000; Iyer et al., 2010; Feşteu., 1998).

Pada teori kognitif sosial menekankan bahwa tindakan dipengaruhi oleh faktor pribadi, lingkungan dan perilaku yang dinamis dan selalu berinteraksi (Bandura., 1999). Instruksi ini biasanya melibatkan contoh perilaku sosial, umpan balik, praktik langsung, penguatan, mencoba berperilaku, dan perubahan perilaku (Moore et al., 1995).

Selain itu berdasarkan teori belajar sosial, sebagian besar perilaku dipelajari dan dengan demikian instruksi langsung dapat digunakan untuk mengajarkan perilaku sosial yang sesuai (Ormrod., 1999). Tujuan utama dalam mengembangkan orang yang berpendidikan fisik adalah untuk membantu siswa terlibat dalam perilaku sosial yang positif (NAPSE., 2004).

Sesuai dengan hasil penelitian yang dilakukan peneliti menunjukan bahwa terdapat perbedaan yang signifikan antara kelompok eksperimen dan kelompok kontrol dengan hasil statistika $\mathrm{t}_{\text {hitung }}>$ dari $\mathrm{t}_{\text {tabel }}$ yaitu $1,81>1,70$ diperkuat dengan hasil P-value $<0,05$ yaitu $0,04<0,05$. Maka penelitian terdahulu yang menyatakan bahwa dengan pendidikan jasmani dapat meningkatkan perilaku sosial sesuai dengan hasil yang peneliti lakukan seperti pada kelompok kontrol, namun di dalam penelitian ini peneliti memberi penjelasan atau materi mengenai aspek-aspek yang ada di dalam perilaku sosial itu sendiri yang diintegrasikan pada kelompok eksperimen sehingga mendapat peningkatan yang jauh di atas kelompok kontrol sebesar $89 \%$.

\section{KESIMPULAN}

Penelitian ini menemukan temuan baru yang menunjukkan kenyataan berbeda dengan hasil penelitian terdahulu. Mengingat keinginan untuk memperkuat perilaku sosial yang positif dan mengurangi perilaku intimidasi dan dampak buruknya terhadap kesehatan mental (Kaltiala-Heino et al., 2000), ada baiknya untuk mengeksplorasi faktor-faktor yang dapat memprediksi perilaku sosial dalam pendidikan jasmani. Faktor-faktor tersebut ialah aspek yang terdapat dalam perilaku sosial menurut Krech et al (1982) bahwa perilaku sosial seseorang itu tampak dalam pola respon antar orang yang dinyatakan dengan hubungan timbal balik antar pribadi yang menjadi aspek yang digunakan peneliti dalam penelitiannya untuk meningkatkan perilaku sosial dalam pembelajaran pendidikan jasmani, yang sesuai dengan hasil analisis data dan statistika bahwa terdapat perbedaan dari hasil pretest dan posttest kelompok eksperimen. Terdapat perbedaan dari hasil pretest dan posttest kelompok kontrol, dan terdapat perbedaan yang signifikan antara kelompok eksperimen dan kelompok kontrol. Hasil penelitian ini menunjukkan bahwa secara keseluruhan terdapat perbedaan dari yang dintegrasikan perilaku sosial dengan yang tanpa integrasi perilaku sosial dan pengaruh perilaku sosial pada pembelajaran penjas. Dari hasil penelitian ini sekaligus juga memberikan informasi bagi para pengajar pendidikan jasmani bahwa dengan mengintegrasikan suatu aspek sosial bisa mendapatkan perubahan yang sangat jauh kepada siswanya. Penggunaan metode penelitian dengan integrasi dalam penelitian ini dapat juga dipertimbangkan dalam penelitian selanjutnya dengan memberikan kontrol dan perlakuan terhadap sampel penelitian. Dengan adanya penelitian lebih lanjut terkait kajian ini, diharapkan mampu memberikan sumbangan atau tambahan informasi bagi perkembangan pengetahuan dan keilmuan khususnya pendidikan jasmani kesehatan dan olahraga.

\section{DAFTAR RUJUKAN}

Arikunto, S. (2006). Prosedur Penelitian Ilmiah Suatu pendekatan Praktis. Jakarta:Rineka Cipto.

Bandura, A. (1977). Self-efficacy: Toward a Unifying Theory of Behavioral Change. Psychological Inquiry, 84(2), 191-215. https://doi.org/10.1037//0033-295X.84.2.191.

Bandura, A. (1999). Social Cognitive Theory of Personality. Handbook of Personality: Theory and Research, 
154-196. https://doi.org/10.1016/0749-5978(91)90022-L.

Baron, R. A., \& Byrne. (1991). Sosial Psychology: Understanding Human Interaction. 6 th edition. USA: Allyn \& Bacon.

Budiman, D. (2007). Bahan Ajar MK Psikologi Anak Dalam Penjas PGSD. Bandung: UPI.

Cartledge, G., Gardner, R., \& Ford, D. (2008). Diverse learners and exceptionalities: Culturally responsive teaching in the inclusive classroom. Upper Saddle River, NJ: Pearson.

Chen, K. (2006). Social Skill Intervention fo Students with Emotional/Behavior isorder: A Literature Review from the American Perspective. Academic Journals: Educational Research and Reviews, 1(3), 143-149.

Deci, E. L., \& Ryan, R. M. (1985). Motivasi intrinsik dan penentuan nasib sendiri pada manusia perilaku . New York, NY: Pleno.

Dos Santos, S. J., Hardman, C. M., Barros, S. S. H., Santos, C. D. F. B. F., \& De Barros, M. V. G. (2015). Association between physical activity, participation in Physical Education classes, and social isolation in adolescents. Jornal de Pediatria, 91(6), 543-550. https://doi.org/10.1016/j.jped.2015.01.008.

Dragnea, A., Şerbănoiu, S. \& Tudor, V., (2000). Teoria educaţiei fizice şi sportului / Teori pendidikan jasmani dan olahraga. Bucureşti: Cartea Scolii.

Feşteu, D. (1998). Social learning by physical education lessons in Romania. Doctoral thesis. UK: Brunel University.

Fraenkel, J. R., Wallen, N. E., \& Hyun, H. H. (2013). BIBLLIYOGRAFISI Bulunacak. Climate Change 2013 - The Physical Science Basis (Vol. 53). https://doi.org/10.1017/CBO9781107415324.004

Gratton, C., \& Jones, I. N. (2010). Research Methods for Sport Studies Second Edition. UK: Routledge.

Hurlock, E. B. (1997). Psikologi Perkembangan, Suatu Pendekatan Sepanjang Rentang Kehidupan. Jakarta: Erlangga.

Iyer, R. V., Kochenderfer-Ladd, B., Eisenberg, N., \& Thompson, M. (2010). Peer victimization and effortful control: relations to school engagement and academic achievement. Merrill-Palmer Quarterly, 56, 361387. doi:10.1353/mpq.0.0058.

Juliantine, T., Yudiana, Y., \& Subarjah, H. (2007). Teori Latihan Olahraga. Bandung: Universitas Pendidikan Indonesia.

Kaltiala-Heino, R., Rimpela, M., Rantanen, P., \& Rimpela,A. (2000). Bullying at school—an indicator of adolescents at risk for mental disorders. Journal of Adolescence, 23, 661 - 674. doi:10.1006/ jado.2000.0351.

Krech., Cructhfield., \& Ballachey. (1982). Individual in society. Tokyo: Mc Graw-Hill International Book Company.

Makmun, A. S. (2007). Psikologi Kependidikan Perangkat Pengajaran Modul. Bandung: Remaja Rosdakarya.

Moore, R. J., Cartledge, G., \& K. Heckman. (1995). The effects of social skill instruction and self- monitoring on game-related behaviors of adolescents with emotional disorders. Behavioral Disorders, 20: 253-66.

Mustika. (2013) . Meningkatkan Perilaku Sosial Anak Melalui Karya Wisata Pada Kelompok B Taman KanakKanak Karya Toyyibah Bale. Palu: Uni-versitas Tadulako.

Nansel, T. R., Overpeck, M., Pilla, R. S., Ruan, W. J., Simons-Morton, B., \& Scheidt, P. (2001). Bullying behaviors among US youth: Prevalence and association with psychosocial adjustment. Journal of the American Medical Association, 285, 2094-2100. doi:10.1001/jama.285.16.2094

National Association for Sport and Physical Education (NAPSE). (2004). Moving into the future. National standards for physical education (2nd ed.). Reston, VA: Author.

Ormrod, J. E. (1999). Human Learning. 3rd ed. Upper Saddle River, NJ: Prentice-Hall.

Raluca, M. (2015). Motor Games, Social Learning Alternative Content in Physical Education Lesson. Procedia - Social and Behavioral Sciences, 180 (November 2014), 1289-1296. https://doi.org/10.1016/j. sbspro.2015.02.266.

Sugiyono. (2013). Metode Penelitian Pendidikan. Bandung: Alfabeta.

Undang-Undang Sistem Pendidikan Nasional. (2003). Undang-undangRepublikIndonesia Nomor 20 Tahun 2003 Tentang Sistem Pendidikan. Jakarta: SISDIKNAS. 6. (n.d.).

Vallerand, R. J., \& Losier, G. F. (1999). An integrative analysis of intrinsic and extrinsic motivation in sport. Journal of Applied Sport Psychology, 11(1), 142-169. https://doi.org/10.1080/10413209908402956. 